PRZEGLĄD RUSYCYSTYCZNY 2020, nr 4(172)

\title{
NOTY O AUTORACH
}

\section{JAKUB BOBER}

Absolwent rusycystyki, doktorant na Wydziale Humanistycznym Uniwersytetu Śląskiego. Zainteresowania naukowe: przekładoznawstwo, polsko-rosyjska komparatystyka językoznawcza.

Kontakt: boberjakub@protonmail.com

\section{MICHAE BOHUN}

Dr hab., profesor w Instytucie Filozofii Uniwersytetu Jagiellońskiego. Historyk filozofii i myśli społecznej. Badacz dziejów myśli rosyjskiej i polskiej ze szczególnym uwzględnieniem refleksji politycznej i historiozoficznej. Tłumacz tekstów filozoficznych z języka rosyjskiego, autor trzech monografii z dziejów myśli rosyjskiej oraz wielu artykułów. Obecnie bada ekonomiczne implikacje krytycznych filozofii społecznych.

Kontakt: michal.bohun@uj.edu.pl

\section{ELENA BORISOVA-YURKOVSKAYA}

Dr nauk humanistycznych w zakresie filozofii, zainteresowania naukowe: zagadnienia metafizyczne w rosyjskiej filozofii, literaturze i sztuce Srebrnego Wieku, koncepcje podmiotu w filozofii XX i XXI wieku, filozofia feministyczna. Ważniejsze publikacje: Смерть как событие повседневности в творчестве А. Ремизова и В Розанова, „Slavica Wratislaviensia” 2018; Реконструкция моделей обращения в религиозном опыте Андрея Белого: metanoia u epistrophe, w: Я. Добешевский, Ст. Краевский, Я. Мах (red.), Познание и религия. Эпистемология религиозного опыта в русской и еврейской философской мысли ХХ века, Wydział Filozofii i Socjologii UW, Warszawa 2018; Философские основания мотива «вечного возвращения» в творчестве А. Блока, „Современные гуманитарные исследования», № 1 (80).

Kontakt:jurkowskaelena@gmail.com

\section{JOLANTA BRZYKCY}

Dr hab., prof. UMK, pracownik Katedry Literatur Słowiańskich UMK w Toruniu, badaczka poezji i ego-dokumentów I i II fali emigracji rosyjskiej. Ostatnie publikaсје: Картины Прованса в творчестве Галины Кузнецовой, „Slavia Orientalis” 2018, nr 4; Przedstawić nieprzedstawialne. „Przypowieści” Lwa Gomolickiego jako świadectwo Zagłady, „Przegląd Rusycystyczny” 2019, nr 2; Функция вещной 
детали в поэзии „первой волны” русского зарубежья, w: G. Ojcewicz (red.), Rosja i pamięć o rzeczy. Od emblematu do relikwii, Olsztyn 2019.

Kontakt: tomine@umk.pl

\title{
PIOTR GEUSZKOWSKI
}

Dr, adiunkt. Pracuje w Katedrze Rusycystyki UW, Kierownik Pracowni Mediów w Dawnej i Współczesnej Rosji. Zainteresowania naukowe: polsko-rosyjskie związki historyczne i literackie w XIX-XX wieku. Autor książek: Antyrosja - historyczne wizje Aleksandra Sołżenicyna - próba polskiego odczytania, Neriton, Warszawa 2008; Ф.В. Булгарин в русско-польских отношениях первой половины ХІХ века: эволюция идентичности и политических воззрений, Алетейя, Санкт Петербург 2013, ss. 228; drugie wydanie Санкт Петербург 2014; Barwy polskości. Biografia literacko-polityczna Tadeusza Butharyna, Universitas, Kraków 2018 oraz licznych artykułów w czasopismach i monografiach naukowych.

Kontakt: p.gluszkowski@uw.edu.pl

\begin{abstract}
ADAM JASKÓLSKI
Dr, adiunkt w Katedrze Rusycystyki Uniwersytetu Warszawskiego; ukończył studia doktoranckie na UMK w Toruniu. Zainteresowania badawcze skupiają się wokół pragmatyki, analizy dyskursu ideologicznego oraz rosyjskiej gwary staroobrzędowców mieszkających w Polsce. Najważniejsze publikacje: Dyskurs polityczny $w$ Rosji. Analiza pragmalingwistyczna (Toruń 2014), (red.) Staroprawosławie wczoraj i dziś (Warszawa-Toruń 2018).

Kontakt: a.jaskolski@uw.edu.pl
\end{abstract}

\section{ANNA KOŚCIOŁEK}

Dr hab. nauk humanistycznych, profesor w Katedrze Literatur Słowiańskich Uniwersytetu Mikołaja Kopernika w Toruniu. Filolog rusycysta, literaturoznawca. Zainteresowania naukowe: filozofia człowieka oraz problematyka sacrum w twórczości pisarzy rosyjskich przede wszystkim XIX wieku, duchowość prawosławna, konteksty kulturowe literatury rosyjskiej. Autorka książek: Człowiek Ewangelii w „Dzienniku pisarza” Fiodora Dostojewskiego (Toruń 1994), „Dziennik pisarza” Fiodora Dostojewskiego. Próba monografii (Toruń 2000),Wybrane fragmenty z korespondencji z przyjaciótmi”. O ideowych poszukiwaniach Mikołaja Gogola (Toruń 2004).

Kontakt: anna.kosciolek@umk.pl

\section{IWONA KRYCKA-MICHNOWSKA}

Dr hab., adiunkt w Katedrze Studiów Interkulturowych Europy Środkowo-Wschodniej Uniwersytetu Warszawskiego. Prowadzi badania w zakresie literaturoznawstwa rosyjskiego ze szczególnym uwzględnieniem dokumentu osobistego, literatury Srebrnego Wieku, pierwszej fali emigracji rosyjskiej, polsko-rosyjskich związków literackich. Autorka monografii na temat dzienników Zinaidy Gippius.

Kontakt: iekrycka@uw.edu.pl

\section{JELENA LEVKIYEVSKAYA}

Dr hab., profesor w Centrum Typologii i Semiotyki Folkloru Rosyjskiego Państwowego Uniwersytetu Humanistycznego (RGGU) w Moskwie; autorka monografii Мифы русского народа (2000), Славянский оберег: семантика и структура (2002), Народная демонология Полесья. Языки славянских культур (we współaut. 
z L.N. Winogradową; t. 1. 2010, t. 2. 2012, t. 3. 2016, t. 4. 2019), a także artykułów o słowiańskiej kulturze tradycyjnej, językach słowiańskich i pragmatyce tekstu.

Kontakt: elena_levka@mail.ru

\section{IRENA MATCZYŃSKA}

Wykładowca Katedry Języków Słowiańskich Wydziału Humanistycznego Uniwersytetu Mikołaja Kopernika w Toruniu. Zajmuje się teorią i praktyką nauczania języka rosyjskiego oraz doskonaleniem organizacji procesu dydaktycznego i wprowadzaniem innowacyjnych metod nauczania. Publikuje artykuły poświęcone tematyce związanej z zainteresowaniami zawodowymi. Jest autorką podręcznika do nauki języka rosyjskiego od podstaw Język rosyjski dla Polaków, Toruń 2019 (cz. 1), 2020 (cz. 2) oraz współautorką podręcznika do nauki języka rosyjskiego od podstaw Русский язык, Charków 2009.

Kontakt: irena.matczynska@gmail.com

\section{MIROSŁAWA MICHALSKA-SUCHANEK}

Dr hab., prof. Uniwersytetu Śląskiego. Obszar zainteresowań: historia literatury rosyjskiej, teoria literatury i dydaktyka języka obcego, z uwzględnieniem języków specjalistycznych (rosyjski język biznesu). Zainteresowania badawcze: literatura wobec tematyki aktów suicydalnych, kategoria nastroju w dziele literackim, literatura a anomalia ludzkiej psychiki, a ostatnio literatura rosyjska a tematyka żydowska. Autorka ponad siedemdziesięciu artykułów i recenzji, a także książek Fenomen samobójstwa (2011), Mit Judasza-samobójcy. Czytając opowiadanie Leonida Andriejewa „Judasz Iszkariot” (2013), Samobójcy Fiodora Dostojewskiego (2015), Piętnaście odsłon Fiodora Dostojewskiego (2018), redaktorka i współredaktorka kilkunastu zbiorowych monografii oraz redaktor naczelna czasopisma „Iudaica Russica”. Kontakt: mirasu@interia.pl

\section{BEATA PAWLETKO}

Dr hab., prof. Uniwersytetu Śląskiego; zatrudniona w Instytucie Literaturoznawstwa na Wydziale Humanistycznym. Redaktor naczelna czasopisma „Rusycystyczne Studia Literaturoznawcze". Zainteresowania badawcze: studia nad pamięcią i traumą w obszarze literatury i kultury rosyjskiej. Ważniejsze publikacje: Josif Brodski i Tomas Venclova wobec emigracji, Katowice 2005; Blokada Leningradu i jej reprezentacje $w$ świetle innych doświadczeń granicznych, Katowice 2016; Wspótczesne kino rosyjskie w obliczu traum wojennych. Kontekst literacki i kulturowy, Katowice 2020 (we współautorstwie z Beatą Waligórską-Olejniczak).

Kontakt: beata.pawletko@us.edu.pl

\section{JOANNA RADOSZ}

Doktorantka literaturoznawstwa w Instytucie Filologii Rosyjskiej i Ukraińskiej UAM w Poznaniu; obecnie pracuje nad rozprawą poświęconą rekonstrukcji rosyjskiego charakteru narodowego we współczesnej fantastyce. Zainteresowania badawcze obejmują współczesną literaturę rosyjską (ze szczególnym uwzględnieniem literatury fantastycznej, popularnej, dziecięcej), manifestacje charakterów narodowych w tekstach kultury oraz komunikację międzykulturową.

Kontakt: joanna.radosz@amu.edu.pl 


\section{OLGA RUBINCZYK}

Dr nauk filologicznych, autorka kilku książek i ponad siedemdziesięciu artykułów o twórczości Anny Achmatowej i jej współczesnych. Wybrane monografie: „Если бы я была живописцем...”: Изобразительное искусство в творческой мастерской Анны Ахматовой (Санкт-Петербург: Серебряный век, 2010); Анна $A x-$ матова и ее время: Избранные работы (Москва: Азбуковник, 2018) oraz, we współautorstwie z Niną Iwanowną Popową, wielokrotnie wznawiana (2001, 2002, 2003, 2004, 2006, 2011, 2012, 2018) Анна Ахматова и Фонтанный Дом (СанктПетербург: Невский диалект, 2000).

Kontakt: rubinchik_olga@mail.ru

\section{ŻANNA SŁADKIEWICZ}

Dr hab., prof. UG, Dyrektor Instytutu Rusycystyki i Studiów Wschodnich Uniwersytetu Gdańskiego, kierownik Zakładu Pragmatyki Komunikacji i Dydaktyki Języka Rosyjskiego. Kierownik Pracowni Badań nad Perswazją Językową; zastępca redaktora naczelnego rocznika „Studia Rossica Gedanensia”, członek PTJ i PTR. Opublikowała ponad 100 prac z zakresu komunikologii, dyskursologii, pragmalingwistyki, socjolingwistyki, frazeologii i glottodydaktyki. Autorka monografii: Политический фельетон в свете теории речевого воздействия (Gdańsk 2013), Здоровъе превыше всего. Коммуникативная ситуация оправдания в дидактическом дискурсе: прагматический и межкультурный аспект (Gdańsk 2019, we współaut.); podręcznika Ćwiczenia z fonetyki języka rosyjskiego dla początkujących (Gdańsk 2014, we współaut.), redaktor naukowy dziesięciu monografii.

Kontakt: zanna.sladkiewicz@ug.edu.pl

\section{ROMAN SZUBIN}

Dr, adiunkt w Zakładzie Pragmatyki Komunikacyjnej Języków Obcych w Instytucie Filologii Rosyjskiej i Ukraińskiej na Uniwersytecie im. Adama Mickiewicza w Poznaniu. Zainteresowania naukowe: hermeneutyka literacka, proza XIX-XXI wieku, twórczość Antona Czechowa, Wasilija Szukszyna, Michaiła Priszwina. Autor publikacji o twórczości Michaiła Priszwina, Wardana Hayrapetiana, Michaiła Szyszkina. Kontakt: szubin@amu.edu.pl

\section{JOANNA WOCH}

Dr nauk humanistycznych w zakresie językoznawstwa, absolwentka Uniwersytetu Łódzkiego (2011 - filologia rosyjska, 2017 - studia doktoranckie). Od 2018 roku adiunkt w Zakładzie Lingwistyki Stosowanej, a od 2019 w Instytucie Językoznawstwa Uniwersytetu Śląskiego. Autorka artykułów naukowych z zakresu ewolucji rosyjskiego podsystemu akcentowego publikowanych w czasopismach polskich i zagranicznych. Zainteresowania naukowe dotyczą przede wszystkim akcentologii języka rosyjskiego (w ujęciu synchronicznym i diachronicznym), słowotwórstwa komparatywnego polsko-rosyjskiego oraz dydaktyki języka rosyjskiego na początkowych etapach nauczania.

Kontakt: woch.joanna@yandex.com

\section{BOŻENA ŻEJMO}

Dr hab., prof. UMK w Katedrze Filologii Słowiańskiej w Toruniu; rusycystka i bułgarystka, literaturoznawczyni. Zainteresowania badawcze: etyka i literatura, transgresje w literaturze i kulturze, twórczość Wsiewołoda Garszyna, pisarz i władza, trauma 
i pamięć. Monografie: Problemy etyczne we wspótczesnej prozie i publicystyce rosyjskiej, Łódź 2000; „Ponad stan”. Motywy transgresyjne w twórczości Jordana Jowkowa, Torun 2010; „Ptaczący Ezop”. Życie i twórczość Wsiewołoda Garszyna, Toruń 2017.

Kontakt: bo.zena@umk.pl

\section{OD REDAKCJI}

W poprzednim (drukowanym) numerze „Przeglądu Rusycystycznego” w spisie treści oraz na okładce został pominięty artykuł p. Sylwii Kamińskiej-Maciąg Pamięć o wielkim terrorze we wspótczesnej literaturze dziecięcej („Breaking Stalin’s Nose” Eugena Yelchina). Za tę pomyłkę Autorkę i P.T. Czytelników serdecznie przepraszamy. 